\title{
DEVELOPMENT OF THE FOREIGN TRADE OF THE UNITED STATES ${ }^{1}$
}

\author{
By Hon. Elihu Root, \\ Secretary of State, Washington, D. C.
}

We are advancing, the whole world is advancing, in the opportunities and in the spirit which create opportunities for that kind of commerce which is profitable and beneficial to both parties the world over. Our relations continually grow more sensible and kindly with all the powers of Europe, with our vigorous and growing neighbor to the north, with our rapidly advancing and developing neighbors to the south, and with the nations that face us on the other side of the Pacific. Little occasions for controversy, little causes for irritation, little incidents of conflicting interests continually arise, as they do among friends and neighbors in the same town, but the general trend of international relations is a trend towards mutual respect, mutual consideration and good understanding.

Of course, our relations to Europe, to the Orient and to Canada have long been much discussed and are worthy of discussion; but it seems to me that the subject which at this particular time opens before us with more of the appearance of new opportunity than any other is the subject of our relations to the Latin-American nations to the south. Just at the time when the United States has reached a point of development in its wonderful resources and accumulation of capital so that it is possible for us to turn our attention from our own internal affairs, to reach out into other lands for investment, the great and fertile and immeasurably rich countries of South America are emerging from the conditions of internal warfare, of continual revolution, of disturbed and unsafe property conditions, and are acquiring stability in government, safety for property, capacity to protect enterprise. So that we mak look with certainty to an enormous increase of population and of wealth throughout the continent of South America, and we may look with certainty for an enormous increase in purchasing power as a consequence of that increase in population and wealth.

${ }^{1}$ An address delivered before the Convention for the Extension of Foreign Commerce held at Washington, D. C., January r4-r6, r907.

(44I) 
These two things coming together spread before us an opportunity for our trade and our enterprise surpassed by none anywhere in the world or at any time. in our history. It was with this view that last summer I spent three months, in response to the kind invitations of various governments of South America, in visiting their capitals, in meeting their leading men, in becoming familiar with their conditions and in trying to represent to them what I believe to be the real relation of respect and kindliness on the part of the people of the United States.

I wish you all could have seen with what genuine reciprocal friendship they accepted the message that I brought to them. We have long been allied to them by political sentiment. Now lies before us the opportunity, with their stable governments and protection for enterprise and property, and our increased capital, to be allied to them also by the bonds of personal intercourse and profitable trade. This situation is accentuated by the fact that we are turning our attention to the south and engaging there in the great enterprise of constructing the Panama Canal. No one can tell what effect that will have upon the commerce of the world, but we do know that there never has been in history a case of a great change in the trade routes of the world which has not powerfully affected the rise and fall of nations, the development of commerce and the development of civilization.

We, by the expenditure of a part of our recently acquired capital, are about to open a new trade route that will bring our Atlantic and Gulf ports into immediate, close intercourse with all the Pacific coasts of South and Central America, and which will bring our Pacific ports into immediate and close relation with all the countries about the Caribbean Sea and the eastern coast of South America. The combination of political sentiment which has long allied us with the Latin-American countries, the opportunity which comes from their change of conditions and our increase of capital and the effects that must necessarily follow the opening of the great trade route of the Panama Canal all point to the development of American enterprise and American trade to the south.

Now in considering that view of the future there are certain practical considerations that necessarily arise. How are we to adapt ourselves to this new condition? How are we to utilize this opportunity? One subject naturally presents itself, and that is 
the increase of means of communication through which our intercourse and our trade may be carried on. And that may be in two ways, one by the promotion of the railroad, long ago projected, and in constant course of development, the road that we speak of as the Pan-American Railroad. When we speak of the PanAmerican Railroad we are speaking of something of the future and which exists to-day only in a great number of links, each of which his its separate name. They are being built and being built with great rapidity. In Mexico, in Guatemala, in Bolivia, in Peru, in the Argentine, in other countries pieces of road are being built, many of them by American capital and American enterprise, some of them by capital coming from other countries, promoted by the strong desire of the people of these Latin-American countries to break out from their isolation and to be brought into contact with the rest of the world. When the work actually under contract is completed, there will be less than 4,000 miles remaining to be built to make a complete railroad, which will unite the City of Washington with the City of Buenos Ayres in the Argentine.

One of the objects of the Rio Conference last summer was to promote and further the interests of all American countries in the building of this road, and I am glad to believe that the action taken by that conference has had that effect. The line now running to the south is almost through Mexico, has almost reached the Guatemala line, and within the life of men now sitting in this room it will be possible for passengers and merchandise to travel by rail practically the entire length of both the North and South American continents.

The other method of communication is that by steamships. In this we are lamentably deficient. A great many fine, swift, commodious lines of steamships run between the South Anerican ports and Europe and very few and comparatively poor ships run between those ports and the ports of the United States. No American line runs south of the Caribbean Sea. Our mails are slow and uncertain. It is a matter of hardship for a passenger to go directly between the great South American ports and the great North American ports, while the mails runs swiftly and certainiy to and from Europe, and it is a pleasure for a passenger to go between one of those ports and the European ports. The Postmaster General reports that the best way for him to get the de- 
spatches from my department to our Ministers in South America with certainty and swiftness is to send them to Europe and have them sent from there to South America. That condition of things ought not to continue if we can prevent it.

One great reason why it exists is that American shipping is driven off the seas by two great obstacles interposed in its way by legislation. One is the legislation of foreign countries which has subsidized foreign shipping; the other is the legislation of our own country, which by the protective tariff has raised the standard of living of all Americans-a most beneficent result-so that American ships paying and feeding their officers and men according to the American standard cannot compete on even terms with foreign ships, the cost of whose officers and men is under the foreign stanclard.

If our government will equalize these artificial disadvantages under which our vessels labor and will clo for them enough to make up the disadvantage caused by raising the standard of living of the men they employ, and the disarlvantage coming from the fact that their foreign competitors are subsidized, we will have an American merchant marine and American ships to carry passengers and freight and mails between South and North American ports. I hope that all of you who agree with me, believing that our government ought to be fair to the American merchant marine, will say so out loud, say so to your neighbor, say so in such a way that American public opinion will realize that that kind of fair treatment is a matter of broad, American public policy.

There is one other subject-very important as a part of this general outlook and forecast of American policy towarcls the south. That is our special relation towards the smaller countries about the Caribbean, and particularly the West Indian, countries, the islands that lie directly on the route between our ports and the Panama Canal. Some of them have had a pretty hard time. The conditions of life in them have been such that it has been difficult for them to maintain stable and orderly governments. They have been cursed, some of them, by frequent revolution. Poor Cuba, with her wonderful climate and richness of soil, has suffered. We have done the best that we could to help her, and we mean to go on cloing the best that we can to help her. 
I think the key of our attitude towards these countries can be put in three sentences:

(I) We do not want to take them for ourselves;

(2) We do not want any foreign nations to take them for themselves ;

(3) We want to help them.

Now, we can help them, help them govern themselves, help them to acquire capacity for self-government, help them along the road that Brazil and the Argentine and Chile and Peru and a number of other South American countries have traveled-up, out of the discord and turmoil of continual revolution into a general public sense of justice and determination to maintain order. There is a good deal of talk about the annexation of Cuba in the newspapers. Never, so long as the people of Cuba do not themselves give up the effort to govern themselves. Our efforts should be towards helping them to be self-governing. That is what we are trying to do now, and what we mean to try to do.

So with Santo Domingo. Poor Santo Domingo! With her phenomenal richness of soil, her people ought to be among the richest and happiest on earth; but that island has been the scene of almost continual revolution and bloodshed. Her politics are purely personal, a continual struggle of this and that and the other man to secure ascendency and power. She has come to us for help. She is burdened with an enormous debt, much of it fraudulent, much of it created by revolutionary governments in the bush or by regular governments in the capital, which, to save themselves from being overthrown, have been ready to make any sort of bargain, to pay any sort of interest, to promise anything to get immediate relief. Many debts have been created in that way and are hanging over the republic like a fog. For the payment of these foreign debts she has pledged the resources of this custom house to creditors from this country, and of that custom house to creditors from that country, and of another custom house to creditors from a third country. With this enormous debt hanging over her like a pall, and with this record of continual revolution and strife depriving her of creclit, depriving her of courage and of hope, she came to us to help her. And we are trying to arrange so that she may have the moral support of the United States, which is necessary to settle her debts, to insure the honest collection of her 
revenue and its application to carry out the settlemen of her debts. We are trying to make an arrangement of that kind by a treaty, trying to perform the office of friendship and discharge the duty of good neighborhood towards Santo Domingo. Our treatment of Santo Domingo, like our treatment of Cuba, is but a part of a great policy which shall in the years to come determine the relations of this vast country, with its wealth and enterprise, to the millions of men and women and the countless millions of trade and treasure of the great world to the south. Our treatment of Santo Domingo, like our treatment of Cuba, is but a part of the working out of the policy of peace and righteousness as the basis for wealth and prosperity, in place of the policy of force, of plunder, of conquest, as the means of acquiring wealth.

The question is frequently asked should not a series of reciprocity treaties be adopted for the purpose of promoting our relations with these southern countries? That is not so important in regard to the South American countries as it might at first seem, because so greatly do the productions of North and South America vary that most of the products of South America already come into the United States free, because they are not competing with our products. Between eighty and ninety per cent of all our imports from South America are now admitted to the United States free of duty. Over ninety per cent of all our imports from the great country of Brazil come in free of duty. So that the field to be covered by reciprocity treaties with those countries is comparatively narrow. There are, however, some countries in regard to whose products I should like very much to see an opportunity to make reciprocity treaties.

But this opens up a broader subject. I do not think that the subject of reciprocity can now be adequately considered or discussed without going into that broader subject, the whole form of our tariff laws.

In my judgment, the United States must come to a maximum and minimum tariff. A single straightout tariff was all very well in the world of single straightout tariffs, but we have passed on during the course of years into a world for the most part of maximum and minimum tariffs, and with our single rate tariff we are left with very little opportunity to reciprocate good treatment from other countries and very little opportunity to defend ourselves 
against bad treatment. Any country in the world can put up its tariff against our products, as compared with similar products from another country, without suffering for it so far as our present laws are concerned. We go on taking that country's products at just the same rates as we did before. Any country in the world knows that if it puts down our products in its tariff it will get no benefit from it, because we will have to charge it the same rates that we charge the country which treats us the worst. The maximum and minimum tariff would be free from one serious difficulty that arises in the negotiation of reciprocity treaties. That difficulty is this: When you make a reciprocity treaty with country $A$, agreeing to receive certain products from that country at less than our tariff schedule, you are immediately confronted by country $B$, which is equally friendly to us, treats us equally well, or perhaps better, and to which we cannot with good grace refuse the same. Then comes country $C$ with the same demand, and D and $E$. The result is that, with that fair and equal treatment which we wish to accord to all countries, there is a tendency by means of successive reciprocity treaties to change the whole form of the tariff, and to change it without that deliberate consideration of the effect upon all American interests which ought to be given in dealing with this complicated and interwoven business of tariff rates. Now, a maximum and minimum tariff would enable us to deal equally with all countries, as we are friendly and ought to be friendly with all countries. It would be free from invidious discrimination, it would enable us to protect ourselves against those that use us badly, to reward those that use us well, and it would proceed upon a general and intelligent consideration of all interests.

There is but one other subject that I want to speak to you about, one to which the convention which met here last year contributed very much, our representation abroad under the American consular system.

The American consular service I had the honor to say here last year has been an exceedingly uneven one. There have been many very good men in it and there have been many men in it who were simply passing the remainder of their days in dignified retirement. That condition came naturally enough when we did not have much foreign trade and we were not pushing ahead for it, but the strain on that machinery has of late years become great. 
We are pushing out in all the world for trade, and our people want information, some of them need it, all want it, and they want to be well represented among the people of the other countries in which they want to do business. And wherever there is a weak spot there is trouble and dissatisfaction. So that with changing times a change in method has become necessary.

Congress passed a law at the last session the material parts of which have been repeatedly brought up for consideration for over thirteen years. It was introduced years ago by men with foresight a little in advance of the practical requirements of the time. Their ideas did not receive endorsement and practical effect until the last session. Congress in the law then passed classified the consulates in different grades. They provided an inspection service, so that now we have inspectors who have been selected from among the most able and efficient consuls and whose business it is to see what consuls are doing and whether they are doing anything, so that now the State Department will not be the last place where information is received about the misdeeds of a consul. They have made provision that all fees should be turned into the treasury and the sole compensation of consuls should be their salary, thus closing the door to temptation.

They did in that act a number of very good things for the consular service. There was a clause in the bill originally which provided that all appointments to the higher positions in the service should be by promotion from the lower positions, and that all appointments to the lower positions should be upon examination. That was stricken out because it was considered that Congress had no constitutional right to limit the President in that way. There is a good deal to be said for that view, but it is equally true of appointments to the army and to the navy, yet there have stood upon the statute books of the United States for many years provisions regulating the promotion there, providing for the filling of higher grades in the army and the navy by promotion, and providing for the appointment to the lower grades only upon a satisfactory examination. And those provisions, while doubtless the President could break over them with the consent of the Senafe; nevertheless have constituted a kind of agreement between the President and the Senate, having the appointing power, and Congress, which creates the offices and appropriates the money to pay 
them, as to how the offices are to be filled. I would like to see that kind of an agreement applied to the consular service, so that the method of selection could be settled, and permanently settled, as it has been in the army and the navy.

Immediately after the passage of the Consular Reorganization Act, with that clause omitted, the President made an order, known as the order of June 27,1906 , in which he provided that all the upper grades should be filled by promotion, and that the lower grades should be filled only upon examination. The order also prescribed the method of the examination, and provided that, as between candidates of equal merit, the appointments should be made so as to equalize them throughout the United States, and should be made without regard to the political affiliations of the candidates. Under that order we will have the opportunity, in filling all of the important consulates, to get the best possible evidence as to whether a man is fit for the important place by scanning the work of the young men in the lower places-a method better than a dozen examinations and better than ten thousand letters of recommendation.

Under that plan we will put in the young men who qualify for the lower grades of places and bar out the lazy fellows that want to fall back on a living they are not energetic enough to get for themselves. When we have seen how the young fellows work in the lower places, we will pick out the men here and there who are born consuls and put them into the higher places. Now, that is the law for this administration. It is good until the $4^{\text {th }}$ of March, 1909. What will become of it then no one can tell. I should be very glad if the public opinion of the country would say to Congress: Agree to this arrangement in such a way that it will be permanent for all time. 